\title{
In Vitro Cardiac Risk Reduction Bioactive Substance from the Seedlings of Echinochloa frumentacea and Panicum sumantrance
}

\author{
Authors \\ Dhasarathan.P, Murfath Yasin.K, Joys Emelda. J, Saranya.S, Sri Iswarya.K \\ A.J.A. Ranjith Singh \\ Department of Biotechnology, Prathyusha Engineering College, Chennai- 602025, India
}

Email:dhasa_rathan@yahoo.co.in

\begin{abstract}
Drug replacement with appropriate remedies are required to eradicate existing problem in thrombosis. It rectified with partially purified thrombolytic enzyme from the seedling of Panicum sumatrance and Echinochola frumentacea. The cell free extract of P. Sumatrance and E. frumentacea seedling was partially purified by dialysis method and observed 36 and $38 \mathrm{KDa}$ molecular weight protein. The isolated enzyme exhibited optimum blood clotting activity at $\mathrm{pH} 7$ at $30^{\circ} \mathrm{C}$. Thrombolytic model used to screen the clot lysis potential of bioactive metabolites and Proteolytic enzyme, extracted seedling. Streptokinase treatment was considered as confirmative and saline water as blank control for this study. The Extracts exhibited a good hemolysis activity and Anticoagulant effect with a maximum activity at $20 \mu$ l concentration in in-vitro condition.

Keyword: P. sumatrance, E. frumentacea, Antithrombosis, Cardiac risk, Phytoremedy.
\end{abstract}

\section{Introduction}

Clotting in blood circulation attack the smooth function of heart it leads to death. Blood clotting is caused different kinds of factors (thrombosis), it increase each year for heart problem. Approximately 1,000,000 patients affected by lung blood clot in USA alone. World Health Organization (WHO) report in $2008^{[1]}, 17.3$ million people death recorded in every year by cardiovascular diseases (CVDs). Thromboses are evolved due to reaction between the platelets and blood vessels, which leads to cause cardiovascular diseases $^{[2]}$. Platelets play major role in blood clot, it reduce the cardiovascular integrity. Some time the platelets are imply on pathological progression of atherosclerotic lesions and arterial vascular thrombosis $^{[3]}$. Aggregation of platelet is developing the uncontrolled activity in arterial thrombosis; it leads to cause the routine function of heart ${ }^{[3]}$. This kind of diseases is controlled using antiplatelet agents $^{[4]}$. Development of aspirin is valuable recovery mechanism of ischemic cardiovascular disorders, it develop hemorrhagic activity and top of gastrointestinal bleeding as disadvantages ${ }^{[3]}$.

From plasminogen, plasmin production inititated by thrombolytic drugs, it defend hemostatic as well as target Thrombo emboli are broken down ${ }^{[4]}$. Plasmin initiated the activity of fibrin, it destruct the blood $\operatorname{clot}^{[5]}$. Phytochemiacal isolated from various plant substances are useful to recovery of coagulant, 
platelet and fibrinolytic activity and there is support consuming such kind of foods in suspected heart patient to avoid heart attack ${ }^{[6]}$. Rutin is an one kind of phytochemicals integrated with the foods. Flavanol obtained in Rutin initiates dissociation of formation of thrombus in blood vessels. Rutin was found to be a good anticoagulant ${ }^{[7]}$. Bacterial organism such as Bacillus natto secreted the natto enzyme it hydrolyse the thrombi as well as convert plasminogen to plasmin.

$P$. sumatrance is cultivated in tropics, used as constant food in financially poor background people in different part of global. This kind of cereals showed various kinds of phytochemicals during screening it acts as antioxidants, intermediate free radical helps to arrest oxidation of fatty acids and oils $^{[8]}$. E. frumentacea (millet) is a species of Echinochola, utilized for traditional and novel methods ${ }^{[9]}$. E. frumentacea having phytochemicals are inhibits digestive tract enzymes. From the above analysis, it is clear that formation of blood clot in the blood vessel leads to a major disease known as CVD (Cardiovascular disease) and the blood clots are generally lysed using fibrinolytic drugs. Thrombolytic drugs are produced from various plant sources of which these two millets $(P$.sumatrance and $E$. frumentaceae) are seemed to be much effective since they both have a wide range of protective compounds that reduces the risk of CVD

\section{Materials and Methods}

Screening of Protein: From the seedling of chosen plants were extracted protein using filtrate by method of Bradford ${ }^{[9]}$. Culture filtrate $(1 \mathrm{ml})$ with mixed $5 \mathrm{ml}$ of $\mathrm{CBB}$ and observed optical density value at $595 \mathrm{~nm}$ in a Beckman DU-50 Spectrophotometer. Aninoculated microbes free medium used as blank and BSA as standard for this experiment.

Fibrinolytic Enzyme Analysis: In this assay $0.5 \mathrm{ml}$ of $1 \%$ casein was added to haemoglobin suspension (0.1 M tris- $\mathrm{HCl}, \mathrm{pH}$ 8.0). Then $0.5 \mathrm{ml}$ of seedling extracts were added separately and incubated at 37 ${ }^{\circ} \mathrm{C}$ for half an hour. At the end of incubation reaction stopped by adding $1.0 \mathrm{ml}$ of $0.15 \%$ trichloro acetic acid. Tyrosine was observed from the reaction contained and recorded at $570 \mathrm{~nm}$. From this value calculated single fibrinolytic enzyme Unit has release $1 \mu$ mole tyrosine per minute.

Separation of protein (SDS-PAGE): Protein separated from the seedling extracts using SDSPAGE by the method of Laemmli ${ }^{[10]}$. Weight of protein determined with help of $100 \mathrm{kDa}$ ladder.

Screening of Caseinolytic activity: Seedling extracts streaked on casein agar medium for screening of casein activity. After streaking Casein plate at $37^{\circ} \mathrm{C}$ for a day, Opaque zone formation confirmed as positive for casein activity after incubation period.

Determination of fibrinolytic activity: Isolated protein stained with silver staining method of Blum. After staining, the gels were stored in $7 \%(\mathrm{v} / \mathrm{v})$ acetic acid. After staining protein solution fibrinogenolytic activity was analysed by modified fibrinogenolytic assay. Fibrinogen $(200 \mu \mathrm{l})$ mixed with the protein sample $(60 \mu \mathrm{l}$ of $0.2 \mathrm{~mol} / \mathrm{l})$ and incubated at $37^{\circ} \mathrm{C}$ and read value at one hour interval upto 3 hours. ${ }^{[11]}$.

Biochemical analysis - Biochemical changes were observed at different ph and temperature. The effect of various fibrinolytic enzyme inhibitors, relative protease activity, metal ions (eg, $\mathrm{Ca}^{2+}, \mathrm{Mg}^{2+}, \mathrm{Al}^{+3}$, $\mathrm{Fe}^{+3}, \mathrm{Na}^{+}, \mathrm{Zn}^{2+}, \mathrm{Hg}^{2+}$, and $\left.\mathrm{Cu}^{2+}[5 \mathrm{mM}]\right)$ and $\mathrm{RBC}$ haemolysis were prepared according to Chinese Pharmacopoeia, 2010 ${ }^{[16]}$. Hemolysis effect was determined by the formula as following:

Hemolysis rate $(\%)=\left(\mathrm{OD}_{\mathrm{t}}-\mathrm{Od}_{\mathrm{nc}}\right) /\left(\mathrm{OD}_{\mathrm{pc}}-\mathrm{OD}_{\mathrm{ncp}}\right) \times$ 100

Anticoagulant analysis: Blood sample $(1 \mathrm{ml})$ with different doses of enzyme (25U, 50U, 75U, 100U) was added with $1 \mathrm{~mL}$ Tris- $\mathrm{HCl}$ and incubated at $37^{\circ} \mathrm{C}$ for $30 \mathrm{~min}$ for observation of anticoagulant effects.

\section{Results}

Growth studies of $\boldsymbol{P}$. sumatrance and $\boldsymbol{E}$. frumentacea seedlings - $P$. sumatrance and $E$. frumentacea seeds were grown in petridishs for 4 days. The germinated seeds was harvested at every 
$24 \mathrm{~h}$ interval and its fibrinolytic activity was measured (Table 1).

Table 1 Growth Studies of $P$. Sumatrance and $E$. Frumentacea Seeds

\begin{tabular}{|l|c|c|c|c|}
\hline S.No & Selected seeds & \multicolumn{3}{|c|}{ Germination of seeds } \\
\cline { 3 - 5 } & & 1 day & 2 day & 3 day \\
\hline 1 & P. sumatrance & $3 \mathrm{~mm}$ & $12 \mathrm{~mm}$ & $20 \mathrm{~mm}$ \\
\hline 2 & E. frumentacea & $2 \mathrm{~mm}$ & $6 \mathrm{~mm}$ & $25 \mathrm{~mm}$ \\
\hline
\end{tabular}

Screening of fibrinolytic activity on selected germinating seeds- Screening of fibrinolytic activity of $P$. sumatrance and $E$. frumentacea seeds on Skimmed milk in the ratio of 0.1 were performed. The result showed higher hydrolytic activity of $19 \mathrm{~mm}$ on E. frumentacea in casein plate assay. Comparatively $17 \mathrm{~mm}$ produced highest hydrolytic zone than $P$. sumatrance germinating seeds.

The Partial characterization of $P$. sumatrance and $E$. frumentacea seedling extract by TLC The $P$. sumatrance and E. frumentacea seedling extract $(5 \mu \mathrm{l})$ loaded on thin layer plate and separated with solvents of hexane, ethyl acetate and acetic acid (10:5:0.5 ratio) and observed under UV 240nm and 360nm (Table-2).

Table 2 The Partial Characterization of $P$. Sumatrance and E. Frumentacea Seedling Extraction

\begin{tabular}{|l|c|c|c|c|}
\hline \multirow{2}{*}{$\begin{array}{l}\text { Normal } \\
\text { Light }\end{array}$} & \multicolumn{2}{|c|}{ P. sumatrance } & \multicolumn{2}{c|}{ E. frumentacea } \\
\cline { 2 - 5 } & $360 \mathrm{~nm}$ & $240 \mathrm{~nm}$ & $360 \mathrm{~nm}$ & $240 \mathrm{~nm}$ \\
\hline- & 0.28 & - & 0.21 & - \\
\hline- & - & 0.30 & 0.35 & - \\
\hline- & 0.51 & 0.51 & - & 0.46 \\
\hline- & 0.62 & - & + & $\begin{array}{c}\text { Seedling } \\
\text { extract }\end{array}$ \\
\hline- & 0.71 & - & 0.69 & 0.69 \\
\hline
\end{tabular}

\section{Purification of fibrinolytic enzyme from $P$.} sumatrance and E. frumentacea seedling - The cell free extract of $P$. sumatrance and $E$. frumentacea seedling was extracted with PBS solution and precipitated with ammonium sulfate. The precipitated protein lyophilized and used to screen the activity of fibrinolyisis. Observation of fibrinolysis shown in Table-3.
Table 3 Purification of Fibrinolytic Enzyme from $P$. sumatrance and E. frumentacea Seedling

\begin{tabular}{|c|c|c|c|c|c|c|c|c|c|c|}
\hline $\begin{array}{r}\text { Purificati } \\
\text { on stage }\end{array}$ & \multicolumn{2}{|c|}{$\begin{array}{c}\text { Activity } \\
\text { U/ml }\end{array}$} & \multicolumn{2}{c|}{$\begin{array}{c}\text { Protein } \\
\mathrm{mg} / \mathrm{ml}\end{array}$} & \multicolumn{2}{c|}{$\begin{array}{c}\text { Specific } \\
\text { activity } \\
\text { U/ml }\end{array}$} & \multicolumn{2}{c|}{$\begin{array}{c}\text { Purificatio } \\
\text { n fold }\end{array}$} & \multicolumn{2}{|c|}{ Yield \% } \\
\cline { 2 - 11 } & P.s & E.f & P.s & E.f & P.s & E.f & P.s & E.f & P.s & E.f \\
\hline $\begin{array}{c}\text { Crude } \\
\text { sample }\end{array}$ & 25 & 25 & 20 & 22 & 1.39 & 1.32 & 1.0 & 1.0 & 100 & 100 \\
\hline Dialyzed & 18 & 18 & 13 & 16 & 1.51 & 1.43 & 1.15 & 1.04 & 76 & 71 \\
\hline $\begin{array}{c}\text { Sephadex } \\
\text { G-75 }\end{array}$ & 12 & 12 & 6 & 8 & 2.8 & 2.3 & 1.42 & 1.38 & 68 & 63 \\
\hline
\end{tabular}

Purification of fibrinolytic enzyme by Sephadex G-75 column chromatography - The concentrated protein $(25 \mathrm{mg}$ ) was loaded on Sephadex G-75 column and fractionaled in 3 types with $30 \mathrm{ml}$ each. Fibrin active protein observed in peak I-fractions from 15 to $38 \& 12$ to 33 peak II-fractions from 43 to $59 \& 45$ to 60 and peak III -fractions from 72 to 83. (Graph 1-2).

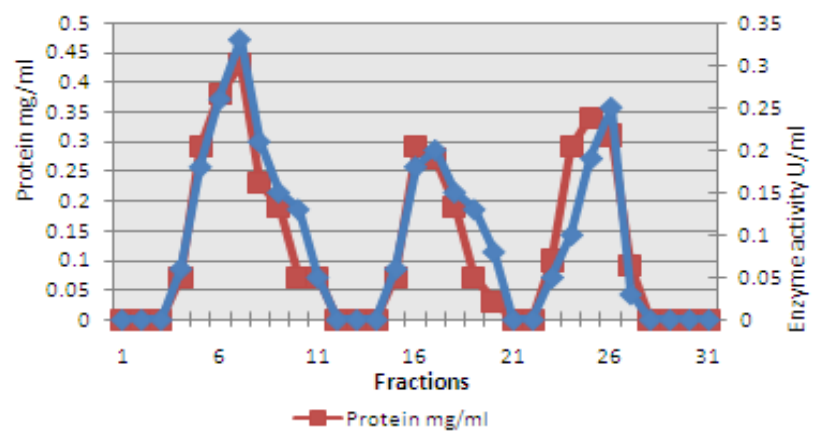

Graph-1 Separation of fibrinolytic enzyme from $P$. sumatrance by Sephadex G-75 columm chromatogram

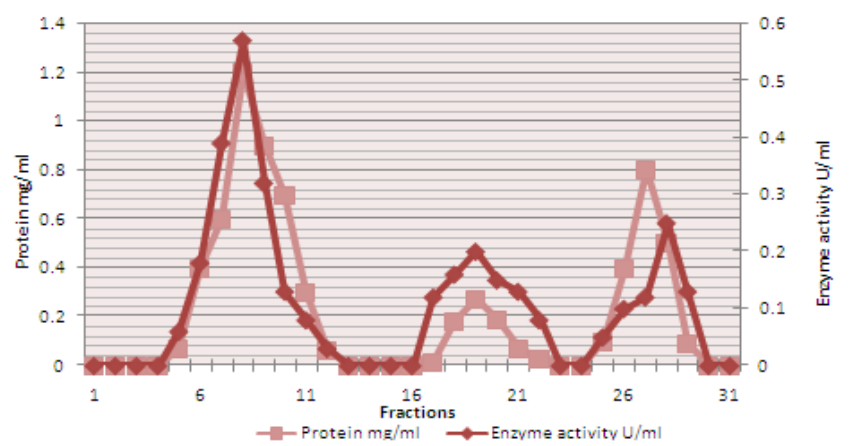

Graph-2. Separation of fibrinolytic enzyme from E.frumentacea by Sephadex G-75 columm chromatogram.

Molecular mass analysis: Isolated protein molecular mass of the fibrinolytic enzyme caluculated as $36 \mathrm{kDa}$ and $38 \mathrm{kDa}$ with help of protein ladder (Fig-1). 


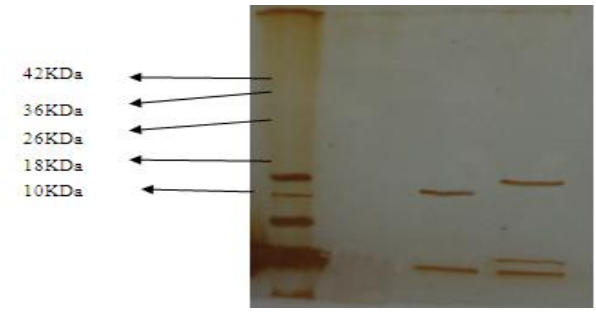

Fig-1 SDS-PAGE patterns of the Partial purified Fibrinolytic enzyme from $P$. sumatrance and $E$. frumentacea seedling

Biochemical characterization of partially purified fibrinolytic enzyme from Panicum sumatrance and E. frumentacea seedling

Effect of pH on the activity and stability: For the screening of $\mathrm{pH}$ optimum was found $\mathrm{pH} 7.0$ as showed effective fibrinolytic activity. The stability of protein is good in broad range of $\mathrm{pH} 6$ to $\mathrm{pH} 9$ (Table-4).

TABLE 4 Effect of $\mathrm{pH}$ on the Activity and Stability of the Fibrinolytic Enzyme from P. sumatrance and E. frumentacea Seedling

\begin{tabular}{|c|c|c|c|c|c|}
\hline \multirow[t]{2}{*}{$\mathrm{pH}$} & \multicolumn{2}{|c|}{ O.D (U/ml) } & \multirow[b]{2}{*}{ 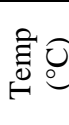 } & \multicolumn{2}{|c|}{ O.D (U/ml) } \\
\hline & $\begin{array}{c}P . \\
\text { sumatrance }\end{array}$ & $\begin{array}{c}E . \\
\text { frumentacea }\end{array}$ & & $\begin{array}{l}\text { P. suma- } \\
\text { trance }\end{array}$ & $\begin{array}{l}\text { E. frumen } \\
\text { tacea }\end{array}$ \\
\hline $\mathrm{pH} 4$ & 0.15 & 0.13 & 20 & 0.15 & 0.13 \\
\hline pH 5 & 0.19 & 0.17 & 30 & 0.20 & 0.17 \\
\hline pH 6 & 0.20 & 0.19 & 40 & 0.18 & 0.16 \\
\hline pH 7 & 0.23 & 0.22 & 50 & 0.16 & 0.15 \\
\hline pH 8 & 0.18 & 0.20 & 60 & 0.12 & 0.10 \\
\hline pH 9 & 0.10 & 0.11 & 70 & 0.10 & 0.09 \\
\hline $\mathrm{pH} 10$ & 0.06 & 0.07 & 80 & 0.06 & 0.05 \\
\hline
\end{tabular}

Effect of Temperature on the activity and stabilityThe activity of protein analyses performed in different temperatures $\left(20^{\circ} \mathrm{C}\right.$ to $\left.70^{\circ} \mathrm{C}\right)$ for 50 minutes. Good responses occur in $20^{\circ} \mathrm{C}$ and $70^{\circ} \mathrm{C}$ and $100 \%$ stable on $40^{\circ} \mathrm{C}$ even after 350 minutes of incubation (Table -4$)$.

Effect of Metal Ions and Inhibitors $-\mathrm{Ca}^{2+}, \mathrm{Mg}^{2+}$, and $\mathrm{Fe}^{2+}$ metal ions were increased and stabilized with fibrinolytic enzyme. $\mathrm{Zn}^{2+}, \mathrm{Cu}^{2+}, \mathrm{pb}, \mathrm{Na}^{+}$, and $\mathrm{Al}^{3+}$ did not show any appreciable effect on enzyme activity were observed and recorded (Table-6). EDTA impact was negligible in fibrionlytc activity was observed and recorded (Table-5).
Table 5 Effect of Various Metal Ions on Fibrinolytic Enzyme Activity

\begin{tabular}{|l|c|c|}
\hline \multirow{2}{*}{$\begin{array}{l}\text { Metal ImM) } \\
\text { Ions }\end{array}$} & \multicolumn{2}{|c|}{ Relative Protease Activity (\%) } \\
\cline { 2 - 3 } & P. sumatrance & E. frumentacea \\
\hline $\mathrm{Zn}^{2+}$ & 100 & 100 \\
\hline $\mathrm{Cu}^{2+}$ & 89 & 78 \\
\hline $\mathrm{Mg}^{2+}$ & 90 & 86 \\
\hline $\mathrm{Ba}^{2+}$ & 109 & 102 \\
\hline $\mathrm{Ca}^{2+}$ & 81 & 74 \\
\hline $\mathrm{Na}^{+}$ & 121 & 116 \\
\hline $\mathrm{Al}^{3+}$ & 93 & 89 \\
\hline $\mathrm{Pb}$ & 79 & 76 \\
\hline $\mathrm{Fe}^{3+}$ & 65 & 60 \\
\hline $\mathrm{EDTA}$ & 101 & 98 \\
\hline
\end{tabular}

Caseinolytic fibrinolytic enzyme purification by $P$. sumatrance and $E$. frumentacea seedlingFibrinolytic enzyme was indeed produced by $P$. sumatrance and E. frumentacea seedling. When the dialysis and purified Fibrinolytic enzyme of $P$. sumatrance and $E$. frumentacea seedling hydrolysed casein showed 19 and $17 \mathrm{~mm}$ zone and purified sample 23 and $20 \mathrm{~mm}$ as $P$. sumatrance and $E$. frumentacea seedlings respectively (Fig-2).
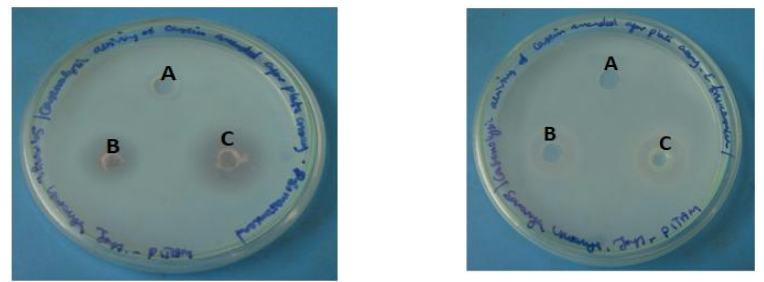

A-Control; B-Dialysis sample C-Partial purified enzyme

Fig-2 Plate assay for caseinolytic activity of processed enzyme

Fibrinolytic activity of $P$. sumatrance and $E$. frumentacea seedling partially purified sample on fibrin plates - Isolated protein hydrolyzed clear zone were measured as 14 and $17 \mathrm{~mm}$ in dialysed sample and 21 and $24 \mathrm{~mm}$ purified sample (Fig-3).

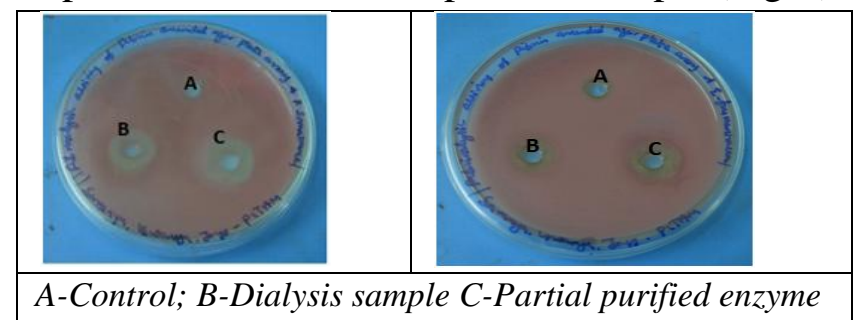

Fig 3 Fibrinolytic activity of $P$. sumatrance and $E$. frumentacea seedling from fibrinolytic enzyme 
Anticoagulant effect: Effects anticoagulant activity of fibrinolytic enzyme observe din megre dose (5U) had no notable effect on clot of human blood. When increase the dose above 200U it involved blodd clott, it observed P.sumatrance anticoagulant more activity than $E$. frumentacea .

Hemolysis: Various concentrations of $P$. Sumatrance and E. frumentacea seedling fibrinolytic enzyme not have shown any remarkable change in hemolysis and agglutination against human erythorocyte cells. Hemolysisrates of high concentration fibrinolytic enzyme (30Uand 40U) were a littlemore than $3 \%(3.23 \%$ and $3.67 \%$, respectively), but low concentration fibrinolytic enzyme (10Uand 20U) did not hemolyzeerythrocytes obviously, and their hemolysis rates were less than $5 \%$.

\section{Discussion}

Fibrinolytic therapy is modern method used to safe and effective methods from food-grade microorganisms ${ }^{[12]}$. It is better than plant isolated protein and alternate method for eliminate the risks of thromboembolic diseases ${ }^{[13]}$. In this study, P.sumatrance and E. frumentacea plants can inhibit the extrinsic coagulation system, which may be the key to antithrombotic and thrombolytic activity. Low dose group (40 U), showed less impact on bleeding and does not affect the body's normal clotting mechanism. Therefore, low dose P.sumatrance and E. frumentacea plants are recommended for the longtermuse to prevent thrombosis.

Antithrombotic activity of fruits and vegetables is scarce, few reports available to inhibit platelet aggregation by induce synthesis of ADP and arachidonic $\operatorname{acid}^{[11]}$. Fibrinolytic enzyme from P.sumatrance and E. frumentacea seedling calculated as $34.0 \mathrm{kDa}$ by gel filtration, which was close to the value SDS-PAGE $(34 \mathrm{kDa})$. The optimum temperature and $\mathrm{pH}$ were $70^{\circ} \mathrm{C}$ and 10.5 , respectively, and the molecular weight was 28,200 as calculated using SDS method. Usama and Ibrahim $^{[12]}$ reported gel filtration chromatography showed Rhizomucormiehei, Fraction I was weakly proteolytic, fraction II showed proteolytic and fibrinolytic activity. The $P$. sumatrance and $E$. frumentacea seedling of fibrinolytic enzyme showed broad $\mathrm{pH}$ at 7.0 optimal temperature of the enzyme was $30^{\circ} \mathrm{C}$. It clarifies the availability of hydrosulfuryl and metal near the active center of the enzyme ${ }^{[14]}$.

\section{Conclusion}

The present findings concluded that P.sumatrance and $E$. frumentacea plants seedling and bioactive metabolites has effective fibrinolytic activity. $P$. sumatrance and E. frumentacea seedling showed lyse globulin, relieve thrombus symptom on healthy human blood, elongate bleeding and clotting time, and also had an anticoagulant. P. sumatrance and $E$. frumentacea seedling has been used to prepare the drug to control thrombosis relevant diseases.

\section{Acknowledgement}

Authors are very much thankful to the Management and Principal for providing facility to carry out this work in lab.

\section{Reference}

1. WHO, "Report of the WHO Technical Reference Group", WHO Headquarters, Geneva, Switzerland, 2008.

2. V.N. Gordon, “A Developmental Perspective", The Personnel and Guidance Journal, 1981, Vol: 59: Pp: 433-439.

3. S. G. Davies, Thomas, S. E, and P.F. Gordon, General and Synthetic Methods, 1986, 8, 312.

4. S. Johnson, "Known knowns and known unknowns: risks associated with combination antithrombotic therapy," Thrombosis Research, 2008, vol. 123 (1), Pp. S7-S11.

5. JL. Zehnder, "Drugs used in disorders of coagulation. In: Basic and Clinical Pharm", Tata-McGraw-Hill publishers, 2009, 11th ed., Pp.597. 
6. PN. Bennett and ML. Brown, "Clinical Pharmacology", Churchill Livingstone Publishers, New York, 2003, 9th ed., Pp.28.

7. V.Kuntić, I. Filipović, Z. Vujić, "Effects of Rutin and Hesperidin and Their Al(III) and $\mathrm{Cu}(\mathrm{II})$ Complexes on in Vitro Plasma Coagulation Assays", Molecules 2011, 16, 1378-1388.

8. J. Vanithasri, S. Kanchana, G. Hemalatha, C. Vanniarajan, and M. SahulHameed, "Role of millets and its importance in new mellinium", Int.J. Food Sci. T echnol. 2012, Vol- 2(1):35-47.

9. MM. Bradford, A rapid and sensitive method for the quantitation of microgram quantities of protein utilizing the principle of protein-dye binding, Analytical Biochemistry [01 May 1976, 72:248-254.

10. U.K. Lammeli, "Cleavage of Structural Proteins during the Assembly of the Head of Bacteriophage T4, Nature, 1970, vol: 227, Pp: 680-685.

11. M. Fujita, K. Hong and Y. Ito, "Transport of nattokinase across the rat intestinal tract" Biol Pharm Bull , 1995, 18(9):Pp.11941196.

12. HA. Guglielmone, AM. Agnese, SC. Nunez Montoya, and JL Cabrera, "Anticoagulant effect and action mechanism of sulphated flavonoids from Flaveriabidentis", Thromb Res, 2002, Vol: 105, Pp.183-188.

13. K. Matsubara, H. Sumi, K. Hori, and K. Miyazawa, "Purification and characterization of two fibrinolytic enzymes from a marine green alga, Codiumintricatum". Comp Biochem Physiol Biochem MolBio, 1998, Vol (1119):Pp.177-181.

14. F. Usama, Ali and Z.M. Ibrahim, "Production and some properties of Fibrinolytic enzyme from Rhizomucormiehei (Cooney \& Emerson) Schipper", Journal of applied science Research, 2008, 4(7): Pp.892-899. 